Education and Science, Mr Gerald Fowler. The talks centred on how the universities could accommodate the expected growth in student numbers which, according to the latest projections, should reach 700,000 by 1981. Working on the Robbins basis of relating entry to higher education with numbers of qualified school leavers, the ministry predicts that 437,000 students will be engaged in full-time higher education in 1971-72, 557,000 in 1976-77 and 727,000 in 1981-82 (compared with the Robbins estimates of $305,000,388,000$ and 510,000 respectively for these years). This expansion is bound to call for a radical reappraisal of the use of university facilities and university financing.

Like the previous conversation with the Committee of Vice-Chancellors and Principals (Nature, 224, 4; 1969), last week's talks were described as informal and in no way embodied positive proposals from either side. If the measures discussed with the Committee of Vice-Chancellors and Principals are anything to go by, however, some very radical proposals for achieving university expansion as cheaply as possible were discussed. The Committee of Vice-Chancellors has circulated a résumé of its diseussions to the universities, and it seems that thirteen possibilities, including reorganization of the academic year and student loans, were put forward. Two year degree courses and six term years were also strongly canvassed.

Other interested parties will soon be appearing at the Department of Education and Science for discussions, and the end product is likely to be a green paper some time next year. This will necessarily include proposals distasteful both to the universities and the National Union of Students. Only if the debate can be removed from the aura of secrecy that has surrounded the talks so far will informed conclusions be reached.

\section{SIXTH FORMS}

\section{Broader Curricula by Half}

\section{from our Education Correspondent}

BREAKING down specialization in secondary school education has long been the objective of British educational reformers. The Joint Working Party on Sixth Form Curriculum and Examinations of the Standing Conference on University Entrance and the Schools Council is at last submitting proposals for broadening sixth form curricula to its parent bodies. These proposals, the result of eighteen months' work, call for two new examinations to be taken at the end of the sixth and seventh school years. Students would specialize much later than under the present system, taking eight subjects in the fifth year, five in the sixth year and two or three in the seventh year. Only in the seventh year would they be able to study exclusively arts or science subjects.

The sixth year examination is seen as a qualifying examination for all sectors of higher education, and would be midway between the present GCE $O$ and A levels. The eurriculum leading to this examination would comprise five subjects for about five-sevenths of the week, with the rest of the time devoted to unexamined studies. Students would have a restricted choice of subjects for the sixth year, spread over a reasonable spectrum of disciplines, and they would be expected to take no more than two sciences or two languages. Normally, all five subjects would be examined at the end of the sixth year, but this does not preclude the possibility of spending more than a year on some subjects.

The joint working party goes on to suggest that specialization in the seventh school year is desirable, and that students should be able to choose two or three subjects for the proposed new Further Examination. University selection would be based on performance in the sixth year qualifying examination, assessment of course work, headmasters' reports and success in not more than three subjects in the further examination. It is also hoped that universities will specify as few subjects as possible by name for their entrance requirements. Students not seeking entrance to degree courses would probably study one or two subjects for the further examination, and some would combine these with continued or new study for subjects in the qualifying examination.

These proposals would, of course, mean an end to the GCE A level examination, but the joint working party emphasizes that it is not seeking to abolish the CSE and O level exammations, which are said to provide many valuable functions, particularly for those not intending to go on to higher education. Students taking the qualifying examination would probably not take $O$ levels, however, because these would no longer be used for university selection purposes. The joint working party also recommends that the qualifying and further examinations should embody the latest examination techniques, and that they should be related as closely as possible to the teaching process. It is therefore hoped that they will not cause the sixth form curriculum to become examination-oriented, and that they will not encroach too much on teaching time.

The working party suggests that the first qualifying examinations should be taken in 1975 , and the first further examinations in 1976. It recommends, however, that the new pattern should be universally adopted, because to run it as an alternative to the present A level pattern would create a system embodying five major public examinations. This would place an undue strain on the country's examination resources, and it would also mean that many schools and universities which would like to support the new system would not do so because of the uncertainties surrounding it. To ensure that the curricula and examinations are correctly planned, a national committee including representatives from the schools and the universities is proposed.

These proposals are half-way towards earlier suggestions from the Standing Committee on University Entrance, which proposed that sixth formers should study five subjects for two years. The Standing Committee says that it was converted to the new proposals because of the advantages of scrapping $O$ levels as a yardstick for university entrance requirements.

\section{UNIVERSITIES \\ Donnish Productivity}

A NUMBER of university academic staff are taking part in a time and motion study. They have been asked by the Committee of Vice-Chancellors and Principals to complete a diary of activities between 8.00 a.m. and midnight for three weeks a year-a normal teach- 